\title{
Flooding of Lake Nakuru National Park and Its Effects on the Resident Wildlife
}

\author{
Peter O. Hongo, Galcano C. Mulaku* \\ Department of Geospatial and Space Technology, University of Nairobi, Nairobi, Kenya \\ Email: peterhongo@gmail.com, *gmulaku@yahoo.com
}

How to cite this paper: Hongo, P.O. and Mulaku, G.C. (2021) Flooding of Lake Nakuru National Park and Its Effects on the Resident Wildlife. Journal of Geographic Information System, 13, 660-670. https://doi.org/10.4236/jgis.2021.136036

Received: August 19, 2021

Accepted: December 17, 2021

Published: December 20, 2021

Copyright $\odot 2021$ by author(s) and Scientific Research Publishing Inc. This work is licensed under the Creative Commons Attribution International License (CC BY 4.0).

http://creativecommons.org/licenses/by/4.0/

\begin{abstract}
Lake Nakuru is one of Kenya's Rift Valley Lakes and lies within the Lake Nakuru National Park. As a key habitat for flamingos and other water birds, the lake is a major tourist attraction. Lake Nakuru National Park covers an area of approximately $188 \mathrm{~km}^{2}$ and is fully enclosed with a perimeter fence. The park is home to about 56 different species of mammals, 550 plant species, and 450 species of terrestrial birds as well as flamingos and other water birds. In the last decade, the lake has experienced continuous flooding, increasing the lake area from $35 \mathrm{~km}^{2}$ in 2009 to $54 \mathrm{~km}^{2}$ in 2018 . This impacted negatively on the available space for wildlife. The main objective of this study was to investigate the effects of this flooding on the wildlife and their habitats in Lake Nakuru National Park. The methodology used Land use Land cover (LULC) interpretation of Landsat Satellite imagery from two epochs, 2009 and 2018, and integration of the results with relevant wildlife data provided by Kenya Wildlife Service. The results, which include LULC change maps and wildlife distribution maps, have shown that the flooding impacted negatively on the available space for wildlife. In addition, the floods also compromised key park infrastructures such as roads and the main gate making it very difficult to maintain the normal park operations, and hence adversely affecting the local and national economies. The information provided by this study is useful for planning mitigation measures in respect of the current and potential future flooding.
\end{abstract}

\section{Keywords}

Flooding, Lake Nakuru, Land Use, Land Cover, Change Detection

\section{Introduction}

\subsection{Background}

Lake Nakuru National Park, covering about $188 \mathrm{~km}^{2}$. was established in 1961 
and has since become a world-famous conservation area, being declared by UNESCO in 1990 and 2002 respectively as a Ramsar Site and a World Heritage Park respectively. The park encompasses Lake Nakuru, the adjacent mountainous vicinity, and the surrounding savannahs. Lake Nakuru is one of the Rift Valley soda lakes, sitting at an elevation of 1760 metres above sea level, and lies between the Bahati Escarpment in the east and the Mau Escarpment [1]. The Lake is just next to Nakuru, the $4^{\text {th }}$ largest town in Kenya with a population of 2.16 million; the lake has for long been world-famous for its large population of flamingos, which have been key in attracting tourists to the area. In addition to flamingos, the park provides habitat for over 300 plant species; 50 different species of mammals; and a variety of terrestrial birds numbering more than 450 species [2].

\subsection{Flooding in Lake Nakuru National Park}

Since 2010 there has been continuous flooding in the park [3], with the result that important park infrastructure such as roads and buildings have been submerged; in addition, the flooding has reduced the Lake Nakuru water salinity, hence negatively affecting the growth of the blue-green algae on which the flamingos feed; furthermore the flooding has submerged some critical wildlife habitats, thus reducing wildlife rangelands, increasing wildlife crowding in the remaining habitats, and aiding in the transmission of animal diseases amongst the wildlife. This has compromised normal park operations and reduced tourist numbers to the park. Plate 1 and Plate 2 show the main entrance to the park before and after the floods.

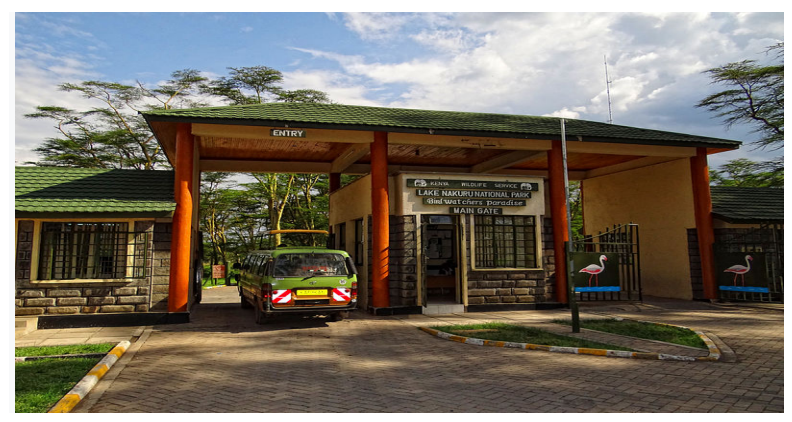

Plate 1. Lake Nakuru National Park main gate in 2009.

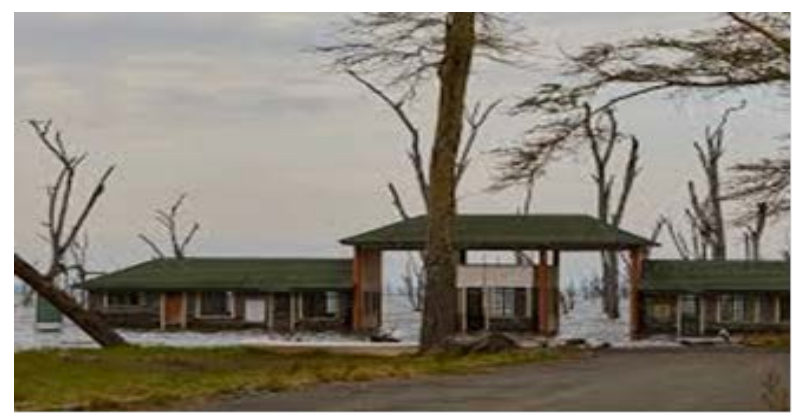

Plate 2. Flooded lake Nakuru National Park main gate in 2014. 
Studies have shown that the main causes of this flooding are poor flood management, inadequate skills in watershed management, poor farming methods, lack of riverine vegetation and deforestation in the relevant catchment areas [4].

\subsection{Remote Sensing in Flood Change Detection}

The flooding of Lake Nakuru National Park and the subsequent economic losses to the local and national economies represents a scenario that calls for mitigation measures, such as a rehabilitation plan and prevention of future flooding. However, such decisions must be based on proper scientific data. Due to the large size of the area involved, the technologies of remote sensing and GIS can be used to efficiently acquire the said information, in terms of how the park has changed over the years of flooding. Such change detection involves the use of multi-temporal datasets to discriminate and quantify areas of land cover change between different epochs of imaging. Alternative approaches include image differencing and image ratioing involving the different epochs [5]. For this study, the first approach was taken. In addition to such mitigation measures (after the flood), remote sensing/GIS can also be used in the other two phases of a flood disaster management cycle, i.e. flood preparedness (before the floods) and flood response (during the floods) [6] [7].

\subsection{Study Objectives}

The key objective of the study was to investigate and document the effects of flooding on wildlife and their habitats in Lake Nakuru National Park; the documentation was to be largely vide land cover change, wildlife distribution and wildlife displaced habitat maps.

\section{Materials and Methods}

\subsection{The Study Area}

The study area consisted of Lake Nakuru National Park and environs, as shown in Figure 1.

\subsection{Methodology}

Data were extracted from the topographical map sheet, Landsat satellite images from 2009 (before flooding) and 2018 (after flooding), and wildlife census records. The data was processed in order to extract the required results of land cover change maps, wildlife distribution and a wildlife displaced habitats map. This methodology is summarized in Figure 2.

\subsection{Data Collection}

Topographical map sheet number $119 / 3$ at 1/50,000, which covers the Lake Nakuru National Park area, was acquired from Survey of Kenya (SoK) in analogue form. For the satellite imagery, a Landsat TM image (resolution $30 \mathrm{~m}$ ) covering the park area was acquired for 2009; for 2018 a Landsat 8 image of the same 


\section{LAKE NAKURU NATIONAL PARK}

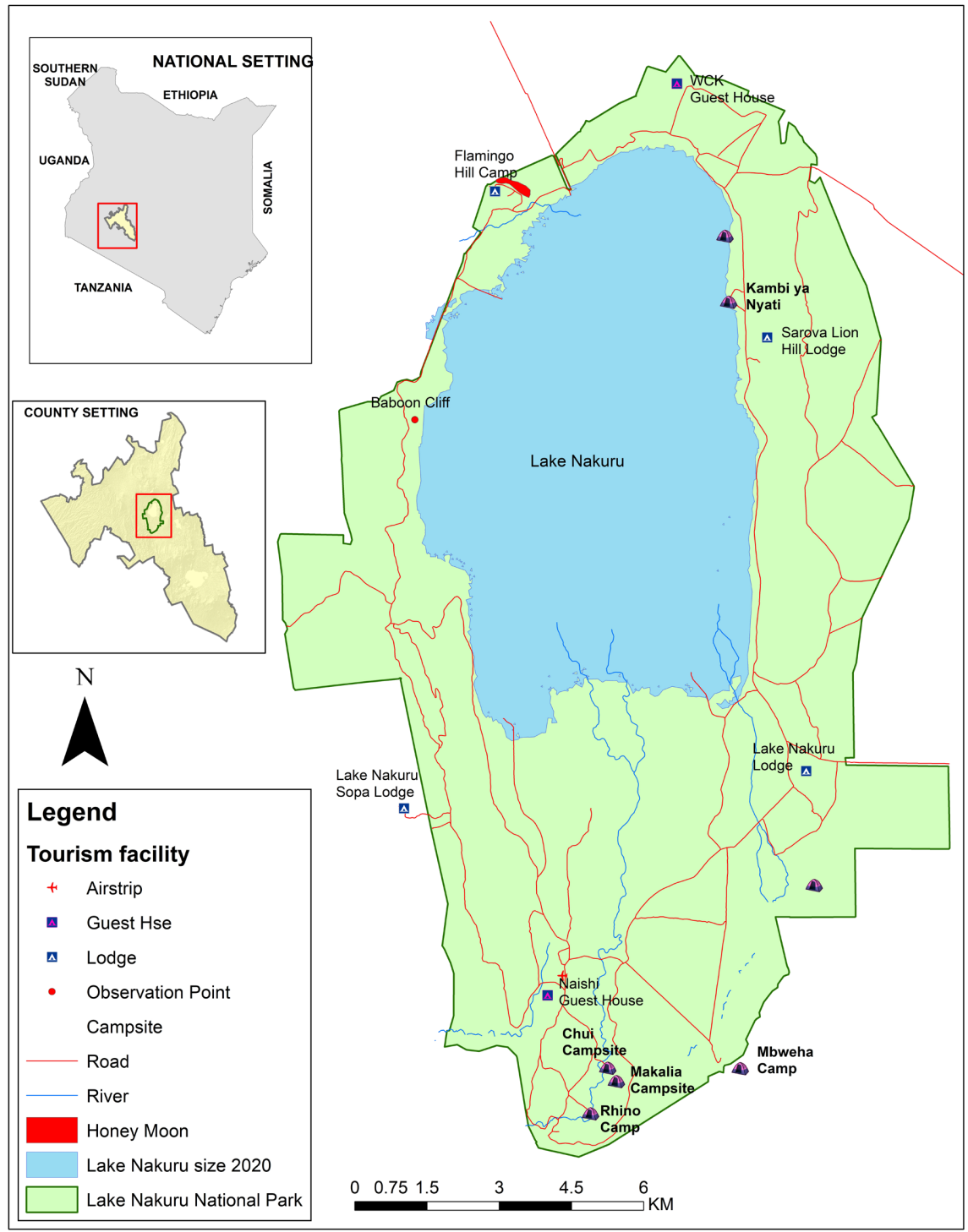

Figure 1. Lake Nakuru National Park and environs (Source: Kenya Wildlife Service).

resolution was acquired. Both images were obtained from the Regional Centre for Mapping of Resources for Development (RCMRD). Wildlife census data (in terms of statistical data and census blocks) was obtained from the Kenya Wildlife Service (KWS).

\subsection{Data Analysis}

\section{1) Topographical map}

This was scanned and input to ArcGIS 10.6 software, where it was georeferenced. From the georeferenced map, basic park features were digitized. These features were to provide a topographical framework/background for subsequent thematic maps from the study.

2) Satellite imagery 


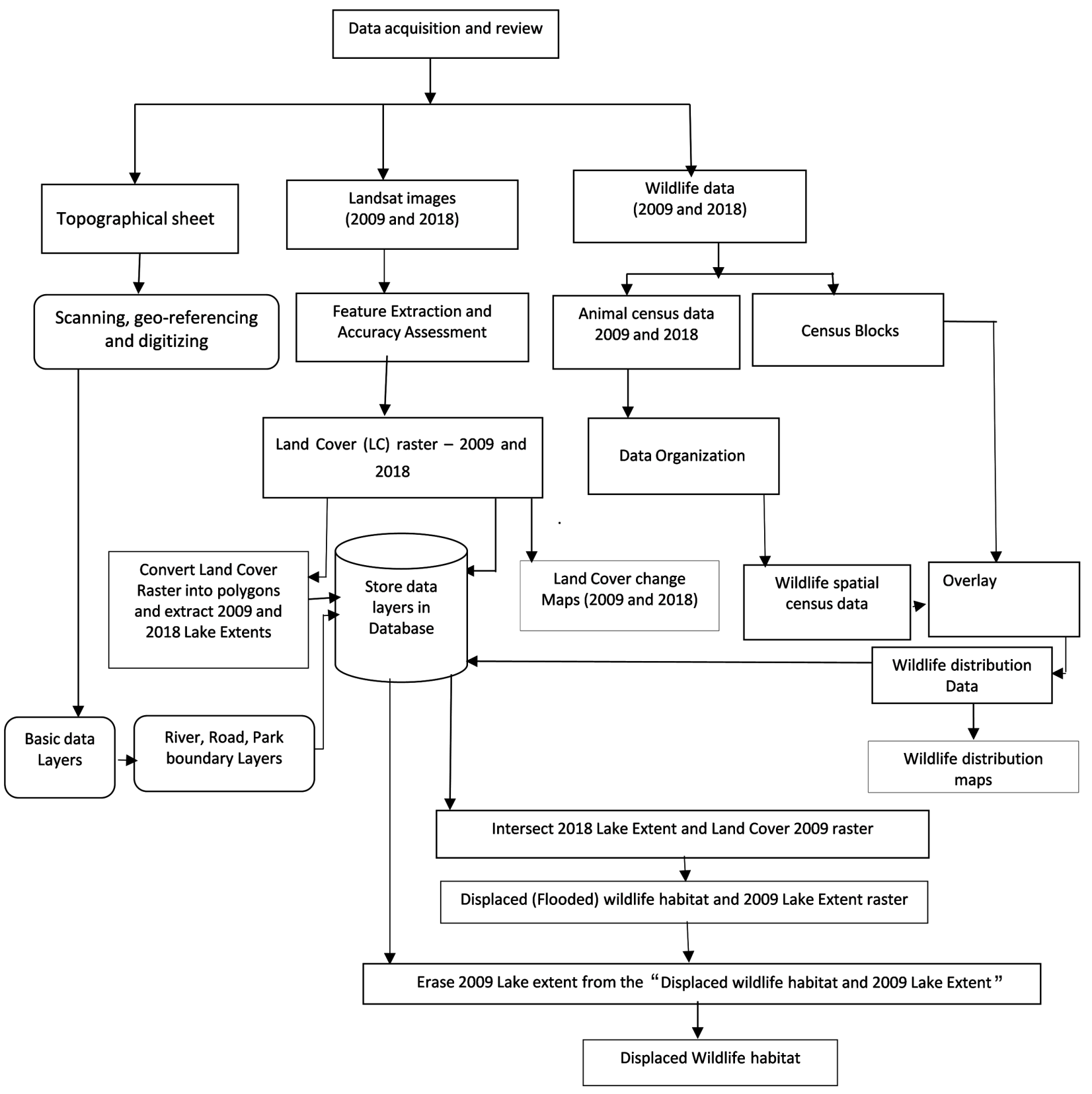

Figure 2. Methodology flow diagram.

The satellite images were first clipped to the area of interest (boundary of the Lake Nakuru National Park), then digitally interpreted for land cover change between 2009 and 2018. Five wildlife habitat classes, namely Lake, Forest, Sewage pond, grassland and Bare ground were chosen for the interpretation. The image classification was also carried out in ArcGIS 10.6, while the accuracy assessment was done in QGIS's AcaTaMa.

\section{3) Wildlife census data}

These data, from 13 blocks, were first rendered into bar graphs for visualization of the numbers at the two epochs, then represented by symbology within the census blocks in order to visualize and compare the total number of wildlife 
and also their distribution within the blocks at the two epochs.

\section{Results and Discussion}

\section{1) Image classification for land use/land cover change}

Figure 3 shows the land cover classification maps for 2009 and 2018; the overall accuracies for these classifications were $73.5 \%$ and $75.0 \%$ respectively.

The subsequent land cover changes are shown in Table 1.

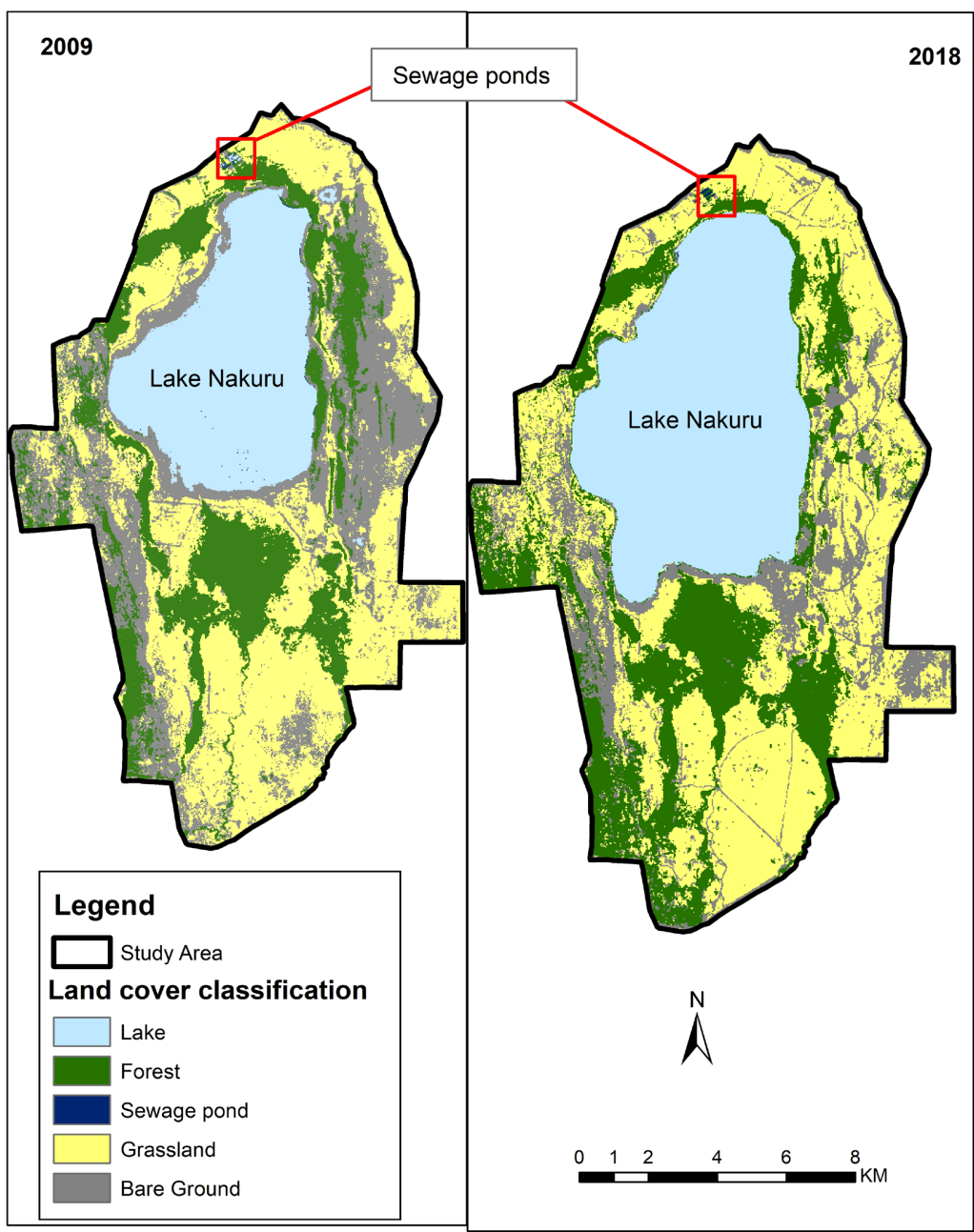

Figure 3. Classification maps for 2009 and 2018.

Table 1. Land cover change.

\begin{tabular}{ccccc}
\hline Land cover category & $\mathbf{2 0 0 9}\left(\mathrm{km}^{2}\right)$ & $\mathbf{2 0 1 8}\left(\mathrm{km}^{2}\right)$ & Change $\left(\mathrm{km}^{2}\right)$ & \% Change \\
\hline Bare ground & 37.38 & 28.83 & -8.55 & -23 \\
Forest & 35.97 & 41.56 & +5.59 & +16 \\
Grassland & 85.56 & 69.78 & -15.78 & -18 \\
Lake & 35.59 & 54.10 & +18.51 & +52 \\
Sewage pond & 0.13 & 0.08 & -0.05 & -38 \\
\hline
\end{tabular}


These results show a clear increase in the Lake category, and a corresponding decrease in the grassland and bare ground categories between the two epochs, which can be attributed to the flooding and growth of the Lake area. The sewage ponds for Nakuru town, which are at the northern edge of the lake, were clearly partly covered by the flooded lake. The reduction in bare ground and grassland represents a reduction in habitat for the animals that normally congregate in those categories.

\section{2) Wildlife data analysis}

Table 2 shows the statistics for the wildlife numbers in the 13 blocks, while Table 3 shows the breakdown of the animal numbers to individual species.

Figures 4-6 show the spatial distribution of the wildlife, by species, at the two epochs of 2009 and 2018. Each map shows a different set of animals; each map also shows the extent of the floodwaters as of 2018, beyond the original lakeshore.

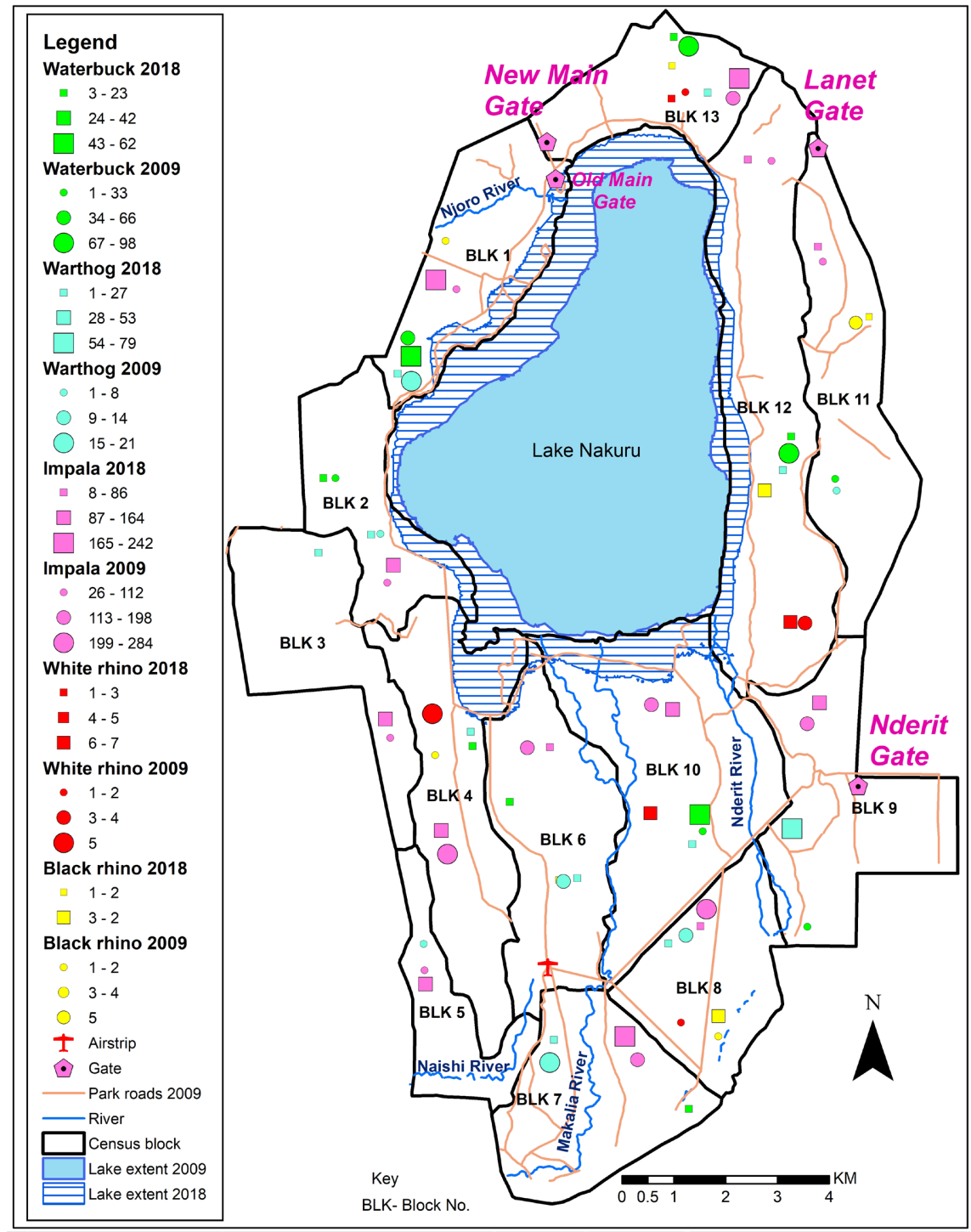

Figure 4. First wildlife distribution map. 
Table 2. Wildlife numbers per census block, densities and standard deviation.

\begin{tabular}{|c|c|c|c|c|c|c|c|c|c|}
\hline $\begin{array}{l}\text { Block } \\
\text { No }\end{array}$ & $\begin{array}{l}\text { X1 (Wildlife } \\
\text { 2009) }\end{array}$ & $\begin{array}{c}\text { X2 (Wildlife } \\
\text { 2018) }\end{array}$ & $\begin{array}{c}\text { Block Area } \\
\left(\mathrm{km}^{2}\right)\end{array}$ & $\begin{array}{c}\text { Density } \\
2009\end{array}$ & $\begin{array}{c}\text { Density } \\
2018\end{array}$ & $\mathrm{X} 1-\mathrm{M} 1$ & $\mathrm{X} 2-\mathrm{M} 2$ & $(\mathrm{X} 1-\mathrm{M} 1)^{2}$ & $(\mathrm{X} 2-\mathrm{M} 2)^{2}$ \\
\hline 1 & 1298 & 522 & 10.20512498 & 127.190995 & 51.15077 & 766.92 & 21.85 & $588,166.29$ & 477.42 \\
\hline 2 & 419 & 421 & 8.462944055 & 49.50995744 & 49.74628 & -112.08 & -79.15 & $12,561.93$ & 6264.72 \\
\hline 3 & 47 & 634 & 9.797976009 & 4.796909072 & 64.70724 & -484.08 & 133.85 & $234,333.45$ & $17,915.82$ \\
\hline 4 & 570 & 371 & 13.10051804 & 43.50972979 & 28.31949 & 38.92 & -129.15 & 1514.77 & $16,679.72$ \\
\hline 5 & 119 & 121 & 5.3239462 & 22.3518412 & 22.7275 & -412.08 & -379.15 & $169,809.93$ & $143,754.7$ \\
\hline 6 & 247 & 315 & 12.12714112 & 20.36753737 & 25.97479 & -284.08 & -185.15 & $80,701.45$ & $34,280.52$ \\
\hline 7 & 276 & 554 & 11.05739053 & 24.96068121 & 50.10224 & -255.08 & 53.85 & $65,065.81$ & 2899.82 \\
\hline 8 & 433 & 497 & 8.872726925 & 48.80123142 & 56.01435 & -98.08 & -3.15 & 9619.69 & 9.92 \\
\hline 9 & 642 & 1077 & 12.41612662 & 51.70694691 & 86.74203 & 110.92 & 576.85 & $12,303.25$ & $332,755.9$ \\
\hline 10 & 664 & 674 & 17.8187106 & 37.26420025 & 37.82541 & 132.92 & 173.85 & $17,667.73$ & $30,223.82$ \\
\hline 11 & 258 & 120 & 12.364713 & 20.86583004 & 9.705037 & -273.08 & -380.15 & $74,572.69$ & 144,514 \\
\hline 12 & 1168 & 497 & 20.84021163 & 56.04549612 & 23.84813 & 636.92 & -3.15 & $405,667.09$ & 9.92 \\
\hline 13 & 763 & 699 & 7.342290011 & 103.9185321 & 95.20191 & 231.92 & 198.85 & $53,786.89$ & $39,541.32$ \\
\hline Total & 6904 & 6502 & & & & & & $1,725,770.92$ & $769,327.7$ \\
\hline Mean & $\mathrm{M} 1=531.08$ & $\mathrm{M} 2=500.15$ & \multicolumn{5}{|c|}{ Variance } & $132,751.61$ & $59,179.05$ \\
\hline \multicolumn{8}{|c|}{ Standard Deviation } & 364.35 & 243.27 \\
\hline
\end{tabular}

Table 3. Mammal numbers counted in April 2009 (before floods) and May 2018 (after floods).

\begin{tabular}{|c|c|c|c|}
\hline Wildlife species & 2009 & 2018 & Change \\
\hline Black rhino & 9 & 7 & -2 \\
\hline Buffalo & 2422 & 2792 & +370 \\
\hline Eland & 20 & 62 & +40 \\
\hline Giraffe & 57 & 92 & +35 \\
\hline Grant's Gazelle & 224 & 188 & -36 \\
\hline Hippopotamus & 2 & 0 & -2 \\
\hline Hyena & 22 & 13 & -9 \\
\hline Impala & 1688 & 1515 & -173 \\
\hline Leopard & 0 & 2 & +2 \\
\hline Lion & 0 & 5 & +5 \\
\hline Thomson's Gazelle & 620 & 313 & -307 \\
\hline Warthog & 315 & 203 & -112 \\
\hline Waterbuck & 232 & 187 & -45 \\
\hline White Rhino & 11 & 15 & +4 \\
\hline Zebra & 1282 & 1108 & -174 \\
\hline Grand Total & 6904 & 6502 & -402 \\
\hline
\end{tabular}




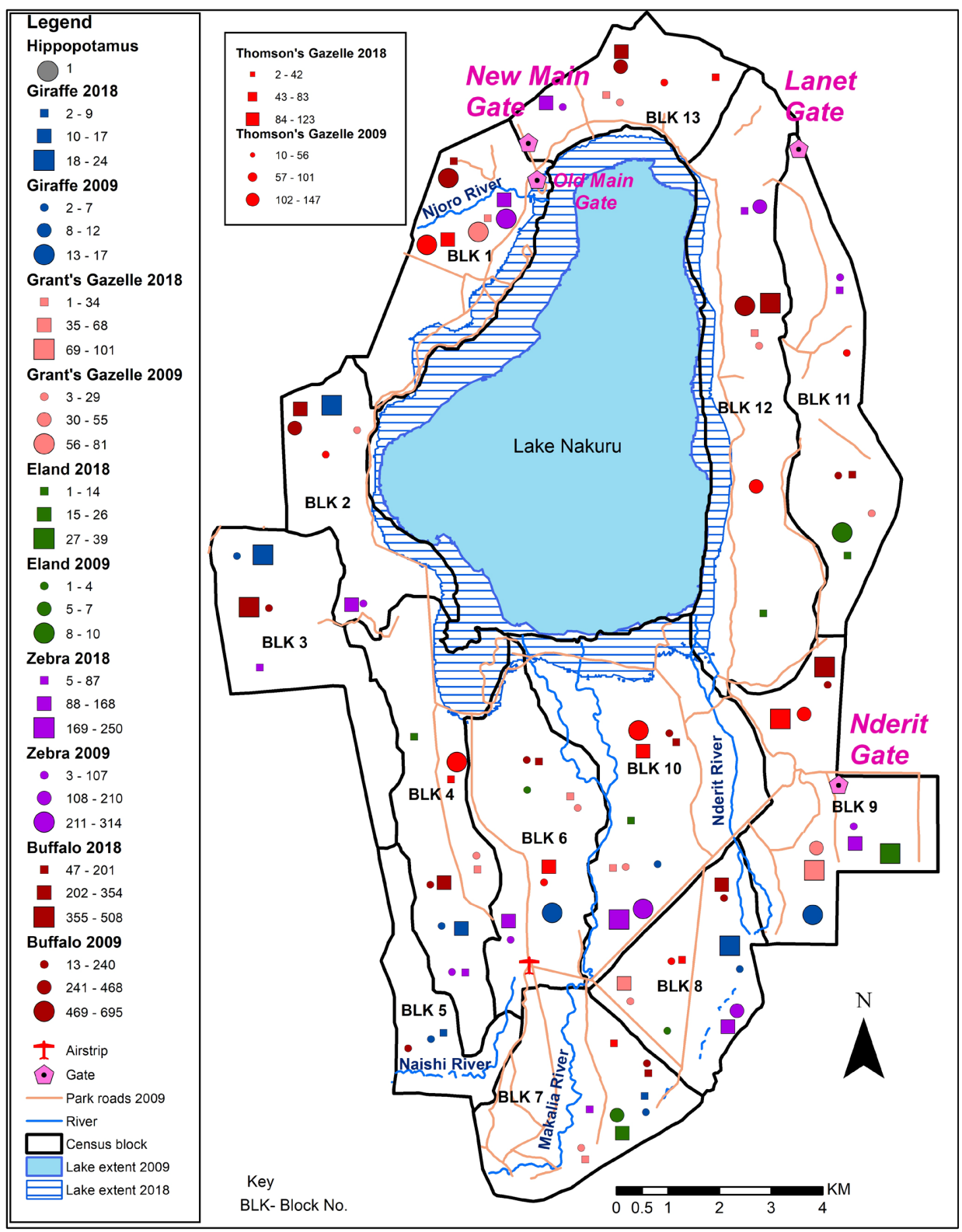

Figure 5. Second wildlife distribution map.

From Table 2 and Table 3, it can be deduced that apart from buffalo, eland and giraffe, all other animal species reduced over the study period, with an overall reduction of about 5.8\%. In addition, it is clear from Figures 4-6 that some species migrated to other blocks as a result of the floods; for example, from Figure 4, it can be observed that large numbers of waterbuck were counted in blocks 12 and 13 in 2009 but these numbers had shifted to blocks 1 and 10 by 2018. This is an indication that the flooding of blocks 12 and 13 made some waterbuck to migrate to blocks 1 and 10. Another example of habitat displacement due to the floods can be deduced from Figure 5, which shows that buffalo, the most numerous animal, registered increased numbers in blocks 3, 4, 8 and 9 after the floods compared to their large numbers in block 1 before the floods. 


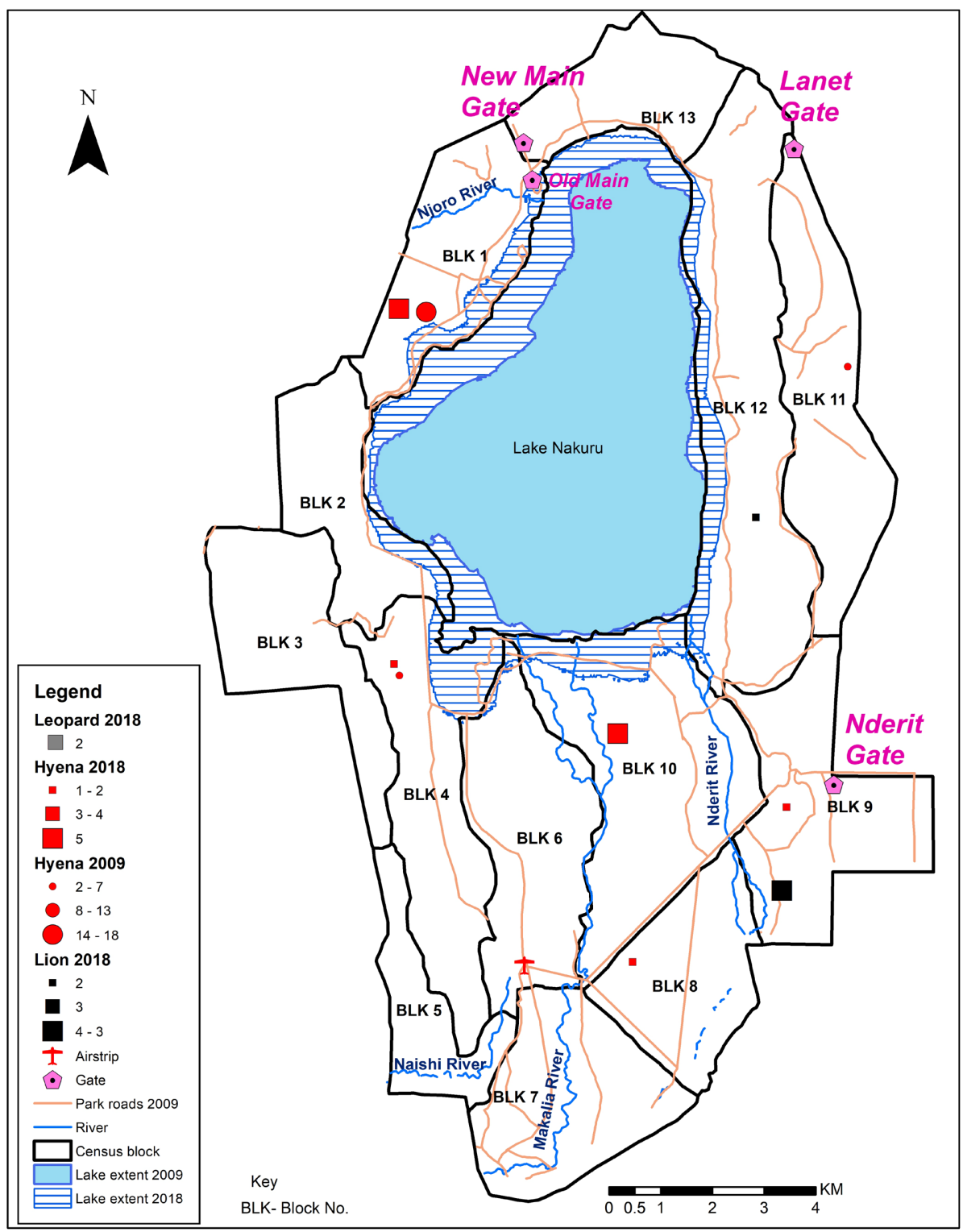

Figure 6. Third wildlife distribution map.

\section{Conclusion}

This paper has documented a study that has quantified the extent of flooding in the Lake Nakuru National Park, and the effects of the flooding on wildlife habitats in the park. The wildlife habitats affected included bare ground, grassland and forest. This led to a reduction of wildlife dispersal areas and especially limited their territories near the lake, which in turn led to the migration of some species, such as rhinos, giraffes and elands from their original habitats to new unflooded habitats. The floods also adversely affected some park infrastructure such as roads and the main gate rendering normal park operations difficult. The results of this study have demonstrated the ability of remote sensing and GIS for this kind of study and can be used to inform decisions on park rehabilitation and future floods prevention and mitigation. 


\section{Acknowledgements}

The authors thank the Almighty God for providing them with the strength and wisdom to carry out this research work. They then acknowledge the support of the Kenya Wildlife Service, Prof. Kennedy Mkutu of UISU, Dr. Patrick Omondi, Dr. Dominic Mijele and Linus Kariuki (all of KWS) and Nobuhiko Yoshimura of JICA in the execution of the research described in this paper.

\section{Conflicts of Interest}

The authors declare no conflict of interest regarding the publication of this paper.

\section{References}

[1] Montcoudiol, N., Burnside, M.N., Gyore, D., Maarita, N., Mutia, T. and Boyce, A. (2019) Surface and Groundwater Hydrochemistry of the Menengai Caldera Geothermal Field and Surrounding Nakuru County, Kenya. Energies, 12, Article No. 3131. https://doi.org/10.3390/en12163131

[2] Shah, P.S. (2016) Domestication and Application of Biodiversity Related Multilateral Environmental Agreements (Meas) in Kenya, Nairobi: UoN Digital Repository Home. http://www.uonbi.ac.ke

[3] Huho, M.J., Mungai, M., Kinuthia, T. and Kosonei, C.R. (2014) Opportunities from Satellite Observation Systems in Climate Risk Mitigation: The Case of Tourism and Hospitality Industry in Lake Nakuru National Park, Kenya. International Journal of Science and Research (IJSR), 3, 1591.

[4] Penney, J. (2015) Kenya's Delicate Lake Nakuru under Pressure from Growing Population, Nakuru County: Reuters.

https://www.reuters.com/article/us-climatechange-summit-earthprints-keny-idUS HNOSG11Y20151022

[5] Lillesand, T. and Kiefer, R. (1994) Remote Sensing and Image Interpretation. 750. John Wiley \& Sons, Chichester.

[6] Rao, S., Bhatt, C. and Sharma, M.B.A. (2012) Flood Monitoring and Management using Remote Sensing. ResearchGate.net, Issue 260753928.

[7] Haq, M., Akhtar, M., Muhammad, S., Paris, S. and Rahmattulah, J. (2012) Techniques of Remote Sensing and GIS for Flood Monitoring and Damage Assessment: A Case Study of Sindh Province, Pakistan. The Egyptian Journal of Remote Sensing and Space Sciences, 15, 135-141. https://doi.org/10.1016/j.ejrs.2012.07.002 